du Toit, A. (2018). Without the blanket of the land: agrarian change and biopolitics in postApartheid South Africa.

The Journal of Peasant Studies, 45(5-6): 1086-1107.

\title{
Without the blanket of the land: agrarian change and biopolitics in post-Apartheid South Africa
}

\author{
Andries du Toit
}

\begin{abstract}
This paper connects Marxist approaches to the agrarian political economy of South Africa with post-Marshallian and Foucauldian analyses of distributional regimes and late capitalist governmentality. Looking at South Africa's stalled agrarian transition through the lens of biopolitics as well as class analysis can make visible otherwise disregarded connections between processes of agrarian change and broader contests about the terms of social and economic incorporation into the South African social and political order before, during and after Apartheid. This can bring a fresh sense of the broader political implications of the course of agrarian change in South Africa, and helps contextualise the enduring salience of land as a flashpoint within South Africa's unresolved democratic transition.
\end{abstract}

\author{
Ukufinyezwa nokubiywa komhlaba \\ Batsho bon'abantwana begazi, \\ Noxa lon'ilizwe lingalesilo lethu. \\ Lo mhlab' uza kusongwa ngokwengubo, \\ Ube ngangentende yesandla. \\ Inkabi yeleqe yogaxelek' ezingcingweni, \\ Ayisakuba naw'amandl' okuxhentsa, \\ lya kubidudekile yidyokhwe nayipuluwa. \\ Sigilane ngezfuba njengezabonkol' emcepheni \\ lintombi zethu zolotyolwa ngamaqhosha \\ Izintwe' ezi man' ukuqhawuka zihlangana \\ Kuthiwa namhl' igazi malingaphalali, \\ Ukuhlanganis' amathile namathile; \\ Ukuze singakhothani njengemaz' ikoth'ithole \\ Iqhutywa luthando nabubushushu begazi. \\ Linako n'ighosh ukukhoth' elinye? \\ Ew' indod' igilane nomolokazana, \\ Unyan' angamhlonel' uninazala, \\ Sisong' amadolo singabi nak' ukunaba \\ Kub' umhlab' ufinyeziwe
}

by St J Page Yako (Yako 1983).

Translated from isiXhosa by Robert Kavanagh en Z.S. Qangule (Kavanagh and Qangule 1971)

\author{
The Contraction and Enclosure of the Land \\ Thus spake the heirs of the land \\ Although it is no longer ours. \\ This land will be folded like a blanket \\ Till it is like the palm of a hand. \\ The racing ox will be entangled in the wire, \\ Too weak to dance free, it will be worn out \\ By the dance of the yoke and the plough. \\ They will crowd us together like tadpoles in a \\ calabash ladle. Our girls \\ Will have their lobola paid with paper, \\ Coins that come and go, come and go. \\ Blood should not be spilled so they say \\ Nowadays, to unite the different peoples, \\ Until we no longer care for each other \\ As a cow licks her calf, when love and nature urges her to do so \\ Can money bring people together? \\ Yes, a man may have words with his son's wife, \\ His son no longer need to respect her mother. \\ Yes, we fold up our knees, It's impossible to stretch out \\ Because the land has been hedged in.
}




\section{Introduction'}

This paper explores the contribution of critical theory to the understanding of the agrarian roots and the political consequences of inequality and poverty in South Africa and stakes out an agenda for future exploration and research. It argues, firstly, that an appreciation of the significance and consequences of agrarian restructuring can be enriched by considering not only Marxist agrarian 'political economy' but also the analysis of welfare capitalism and distributional regimes, and Foucauldian accounts of biopolitics and governmentality. These allow us to link an understanding of the socio-economic dynamics of jobless deagrarianization' with an account of the incorporation of landless black people within the South African social and political order. The replacement of the 'blanket of the land' in Yako's poem by the order of money and commoditised relationships had implications, not only for the relations of production, but also for contestations about the nature of social citizenship in South Africa - and the arts of government that could give effect and content to such citizenship.

Secondly, it argues that this research agenda, focused on an understanding of the connections between agrarian change and biopolitical incorporation, can help situate contemporary South African arguments about land politics in a more fertile terrain. Public debates about the stakes and direction of land reform in South African are generally framed in terms that render them unproductive and sterile, partly because they are divorced from the realities of agrarian change over the last three decades, and partly because the land issue is bound up with larger unresolved questions about the meaning and nature of South African citizenship. This paper is written in the hope that a theoretically enriched approach can help liberate land and agrarian policy debates from the 'agrarian' ghetto within which they are so often caught, and can illuminate the connections between the dynamics of rural livelihoods and agro-food restructuring and broader debates around democracy, government, and political modernity.

I begin by briefly raising some questions about land reform politics in present-day South Africa, and the disconnections between these and other domains of political debate. I then summarise some insights from scholarship on the political economy of agro-food restructuring, and consider how these can be complemented by theories of welfare capitalism, distributional politics and governmentality. The next section indicates how these approaches can illuminate key features of change in twentieth century South Africa. This is followed by a summary of salient aspects of post-Apartheid biopolitics as seen from this viewpoint, and the identification of key areas for more research. Finally, I consider some of the broader political implications of the 'thwarted biopolitics' of postApartheid South Africa.

\section{Outoftheagrarianghetto}

Current debates about land reform in South Africa are characterised by a peculiar disjuncture. On the one hand, among white and black South Africans, popular concern with

\footnotetext{
${ }^{1}$ An earlier version of this paper was presented at the BICAS international conference Rural Transformations and Food Systems - The BRICS and Agrarian Change in the Global South on 20-21 April 2015 at the University of the Western Cape.
} 
land redistribution is dominated by a frame of reference that equates the 'land question' with the 'national question'. As a result, the issue of whom the land should belong to is often tangled up with unresolved questions about whose country South Africa really is, and the case for land reform is informed in the first place by moral arguments about restorative justice, the need to heal the wounds of the past and the need to establish a legitimate postcolonial order. On the other hand, policy proposals have approached the land question almost exclusively within a 'productionist' framework that, as Ferguson put it, conflates land reform with agrarian reform (Ferguson 2013). The question of whom the land should belong to is displaced by questions about who should farm it, and debates about historical right, political pain and restorative justice give way to technical discussions about food security, agricultural productivity and commercial viability. Thus the resolution of complex and incendiary political questions - the need to address living and painfully felt memories of historical injustice, the reality of continued economic and social marginalization and the persistence of deep racial divisions - are taken to depend, inter alia, on the ability of South Africa's beleaguered and dysfunctional department of Rural Development and Land Reform to deliver commercial land reform, on scale, in a context of fiscal austerity, globalization, and local government dysfunction.

The disconnections do not end here. In addition to the mismatch between the languages of public debate and those of technical policy deliberation, policy debates themselves seem to proceed in isolation from the basic facts of South African agrarian structure. The avowed aim of land reform policy is not to support the incomes of the poor but to 'rekindle the class of black commercial farmers that was disrupted by the 1913 Natives Land Act' (Republic of South Africa 2015): an expensive form of 'narrow' black economic empowerment that has no prospect of transforming South Africa's agrarian structure (Cousins 2015). Aimed at emerging black capitalists and committed to 'strategic partnerships' with established commercial farmers and agribusiness, it is susceptible to elite capture (Hall and Kepe 2017). Moreover, implemented in the teeth of climate change, and in the context of rapid agro-food restructuring that has tilted the balance of market power in favour of big retail and financial capital (Bernstein 2013), it has no chance of success even on its own terms. Strangely enough, while critical agrarian scholars have subjected government's plans for recreating a class of black capitalist farmers to withering critique, much of their research too has tended to remain caught within the conceptual boundaries of 'productionism', privileging farming among the wide range of livelihood and survival activities on which poor rural people rely, and focusing overly on the prospects of agriculture providing poor and rural households with a path for 'accumulation from below' (Cousins 2013). Most strikingly, the debate has remained resolutely rural in focus - in spite of the fact that a significant majority of South Africa's poor and landless people are now living in the cities. While the material and political consequences of landlessness resonate through the urban areas, much of the discussion about the prospects, aims and likely beneficiaries of land reform has remained weirdly siloed: located almost entirely within the spatial imaginary of rural South Africa. 
Almost twenty-five years after the transition to democracy, discussions about land reform are thus at an impasse. While land reform is widely acknowledged to be in crisis, there is no broadly accepted understanding of why this is so. Some attribute failure to technical problems such as the inability to establish adequate institutions, appropriate finance mechanisms or effective partnerships; more popularly it is seen as a simple failure of political will. In recent years, the reliance on willing buyer/willing seller market mechanisms and the constitutional protection of private property have been the preferred targets for blame (see e.g. Palm 2018).

As James Ferguson has pointed out, one of the things missing from this debate is a sense of what land reform is for. A clearer sense is needed of how land and landlessness affects the present-day politics of poverty in urban as well as rural contexts - and of what land reform can or cannot do. In particular, if practical answers to the distribution of land and security of tenure are to be found, agrarian scholarship has to find its way out of the conceptual ghetto imposed by an over-focus on issues of agricultural production, and develop a better understanding of the multiple connections between struggles around land and wider questions about the nature and design of South Africa's distributive order - and the meaning and value of citizenship itself.

\section{Distributional regimes and biopolitics}

One purpose of this paper is to re-situate land and agrarian politics within a broader understanding of the politics of inequality and social citizenship in South Africa. The readers of this journal will be familiar with the insights afforded by Marxist political economy and 'radical' agrarian social history. For now it is enough to say that these traditions, along with recent innovations in Global Value Chain (GVC) and Global Production Network (GPN) theory, have critiqued policy discourses that naïvely link the prospects for equitable social change in South Africa's rural areas to prescriptions for inclusion in capitalist growth, access to markets and global financial integration (Mbeki 2003; CDE 2006; Prahalad 2006; De Soto 2010). Inter alia, a Marxist account of South Africa's 'stalled agrarian transition' shows how capitalist development has led to the adverse incorporation of the fragmented classes of labour, locking them into dependence on the capitalist economy while marginalising them as workers, farmers, producers and traders (Murray 2002; Bracking 2003; Du Toit 2004; Bernstein 2006, Oya 2009; Du Toit and Neves 2007; Li 2009).

But the full implications of adverse incorporation cannot be understood by considering economic relations alone (Bolwig et al. 2010). Poor and marginalized people are incorporated not only as producers and consumers, but also as citizens and as bearers of rights and identities. What matters is not only the relations of production and the functioning of markets but also the role of the state, the meaning of citizenship and the interactions between the state and those it governs. Understanding these requires more than a purely economic critique of liberal narratives of market inclusion: it is also necessary to investigate the political incorporation and government of poor populations as phenomena in their own right. How should we understand the the changes in the 
form of the state, the content of distributive politics and the nature of the arts of government in post-industrial, post-agrarian, post-colonial societies such as South Africa?

Here, much can be learned from connecting agrarian political economy with the literature on the politics of distributional regimes, social citizenship, and late liberal governmentality. Two traditions are particularly useful: firstly, analyses of 'welfare capitalism' and distributive regimes drawing on the work of $\mathrm{T} \mathrm{H}$ Marshall and Esping-Andersen; and secondly Foucauldian accounts of biopolitics and governmentality.

Social policy studies since Esping-Andersen have taken Marshall's analysis of social citizenship and welfare policies beyond a focus on fiscal redistribution, social protection and the nature of socio-economic rights. Esping Andersen's notion of a 'welfare regime' denotes the entire mix of policies - labour market, social provision and fiscal redistribution - whereby governments seek to affect distributive outcomes in society. He and his students paid particular attention to the different ways that the 'production of welfare' could be allocated between 'state, market and family,' and to how welfare regimes could 'de-commodify' certain services, so that they would not have to be bought on the market but could instead be provided and claimed as a matter of right (Davy, Davy, and Leisering 2013).

In South Africa, this work has been taken further by Jeremy Seekings and Nicoli Nattrass. Discussing the analysis of southern welfare regimes, Seekings has argued that EspingAndersen did not pay sufficient attention to industrial strategy and how states try to influence the growth path of national economies (Seekings 2005). He defines a 'distributive regime' to include not only welfare and redistributive policies but also industrial strategy, industrial relations and workers' rights: the entire complex of arrangements that influence the distribution of the costs and benefits of capitalist economic growth. Seekings and Natrass deployed this notion to great effect in subsequent analyses of the transition into and out of Apartheid and the development of post-Apartheid social policy (Seekings and Nattrass 2005, 2015). They focused with particular care on the differential and uneven ways in which poor people were incorporated into the South African distributional regime: the choices that determined the growth path, the groups supported into or excluded from labour markets, and the legal frameworks governing conflicts and decision making.

Foucauldian scholarship intersects with this tradition in useful ways. Foucault's legacy is of course contested. Some influential scholars read him as a critic of the very possibility of freedom in modernity as such (e.g. Agamben 1998). In this paper, I rather follow those who see him as a theorist of strategic action and practically oriented reflection (Lemke 2002, 2004; Collier 2009; Barnett 2010, 2017). Particularly central for this paper are the Collége de France lectures (Foucault 2003, 2007, 2008). As these volumes show, the distributional arrangements of modern welfare states were also dependent on the development of new forms of governmental power. Firstly, the sovereign's power over the life and death of their subjects - the power to 'take life and let live' - was supplemented by a new focus on the power to 'make live or let die' (Foucault 2003). Secondly, unlike sovereign power 
(conceived primarily as dominion over a territory) these new forms of bureaucratic rule involved a kind of 'pastoral power', concerned with rule over the population as a totality of individual subjects, who were to be governed omnes et singulatim ('each and all') both singly and as a collectivity (Foucault 1981). Thirdly, the rise of pastoral power was linked to the development of distinctively new forms of political reason concerned not with citizenship and the juridico-legal problematic of sovereignty, but with the emerging understanding of human populations and social totalities as natural objects, subject to observable laws, dynamics and processes of their own. This form of political deliberation, which took as its focus the underlying social, biophysical, economic and ecological 'enabling conditions' that could influence the prosperity, the wellbeing and the productivity of populations, is what Foucault called biopolitics (Foucault 2008) ${ }^{2}$

The salience and content of biopolitics are of course not everywhere the same. An obvious point is that Foucault's own work was almost determinedly Eurocentric, focusing mostly on the history of political thought and governmental power in the Graeco-Roman tradition and as developed in France, Germany and England (Said 1979; Pesek 2010; Revel 2013; Young 2016, 395-410). A rich comparative literature has however developed, mapping the similarities and the divergences with Foucault's account in the history of governmental power in the colonial and postcolonial world. Foucault's thought was warmly received particularly by scholars of subaltern studies (Samaddar 2013), encouraging an fertile literature on poverty, bureaucracy and urban government in the Indian subcontinent (see e.g. Roy 2009a, 2009b; Gupta 2012). A particularly useful contribution has been that of Partha Chatterjee, who has pointed out how in the colonial world, the techniques of biopolitical government did not follow in the wake of modern forms of sovereignty and democratic citizenship as they did in Europe, but separately from them, incorporating colonial subjects in 'political society' long before they were included in 'civil society' (Chatterjee 2006). Additionally, Foucault's work influenced the fields of urban studies and human geography, where the analysis of the dissemination of neoliberal governmentality to the 'global South,' including South Africa, has become a veritable industry (Miraftab 2004, 2007; Barnett 2005; Clarke 2008; Parnell and Robinson 2012; Von Schnitzler 2016; Bénit-Gbaffou 2018).

There are many overlaps between the study of biopolitics and distributive regimes. Both are interested in the the differential incorporation of populations within the systems of rights and entitlements that comprise modern states. Both require scholars to pay careful attention to the calculations policymakers make about investments in (and disinvestments from) the health and wellbeing of populations (Li 2009). But there are also significant differences. While the social policy literature focuses on the regulation of capitalism, 'social citizenship' and the rights and entitlements accorded to members of society (EspingAndersen 1990), the literature on governmentality and biopolitics is more concerned with

\footnotetext{
2 'Biopolitics', in other words, is not, as is often supposed, about the management of biological life 'in itself.' As Stephen Collier points out, this depends on a notion of 'biology' as a separate realm of knowledge that did not exist at the historical time Foucault was concerned with (Collier 2011, 17). Rather, it refers to the emerging apprehension of human society as a knowable totality 'defined at the "finitudes" of life (biology), labor (economic activity), and language (sociocultural existence)' (ibid).
} 
the complex and elaborated systems of knowledge production and rational deliberation on which institutions of government rely. (Foucault 1981). How are populations - as a whole, and at the level of individuals - turned into objects of knowledge, management and intervention? What are the forms of administrative and bureaucratic knowledge, of technological rationality, and governmental deliberation associated with the development of modern forms of state power? Such questions can provide the basis for a much more detailed analysis of the micro-politics of political and bureaucratic agendas. Foucault's colleague Donzelot, for instance, has shown how essential the rise of the social and statistical sciences were for the development of social democracy in Europe. They allowed phenomena such as crime, suicide, idleness and prostitution, previously understood as moral problems, to be reframed as 'social facts', produced by clearly definable underlying material conditions, subject to actuarial analysis, and amenable to rational policy management. At the same time new areas of social reality - in particular family life came more sharply into view as privileged sites of moral concern, bureaucratic surveillance and social pedagogy (Donzelot 1988, 1997; Ferguson 2012)

This is not to say that all these traditions fit together seamlessly. Most obviously there are deep disagreements between orthodox Marxist approaches, which seek to reveal the 'economic logic' underlying different modes of production, and the later Foucault's emphasis on the contingent, open-ended and heterogeneous nature of governmental assemblages. The theoretical approach being explored here is thus syncretic. In particular, my analysis is arguably more post-Marxist than Marxist, making use of critical insights about the course and consequences of capitalist economic development without buying into the teleological political theology that often characterises orthodox Marxist theory. My purpose here is not to achieve a new theoretical synthesis, but, following in the lead of Ferguson (2012), to open up an empirical and theoretical conversation between bodies of literature that, particularly in the case of the South African agrarian question, are rarely connected.

\section{Agrarian transition and biopolitics in twentieth-century South Africa}

I have elsewhere (Du Toit 2017) already discussed the outlines of the account of recent South African history that emerges from this literature. To summarise, recent scholarship on the history of biopolitical and and distributive regimes has highlighted their importance in shaping the contours of economic and social inequality and their central role in contests about the nature of the South African racial order and the place of citizenship within it. The South African distributive regime was given definitive shape in the 1920 s and 1930s, when the social struggles accompanying the transition to industrial capitalism forced onto the political agenda the question of the rights, obligations and entitlements that followed from citizenship (Iliffe 1987; Seekings and Nattrass 2005). The outcome was a racialized social pact for settlers constructed around what $\mathrm{T} \mathrm{H}$ Marshall would later and in a different context call 'industrial citizenship' - the notion that the basis for attaining social claims and entitlements was to be provided by the social identities and institutions developing around formal sector employment, primarily of male breadwinners (Marshall 2009; Barchiesi 2011). As in the case of European social democracy, 
this shift was part of a moralising social politics centred on the improvement, upliftment - and intensified government - of 'poor white' families supposedly at risk of decline, moral turpitude and deracination (M. Du Toit 1996; Teppo 2004; Seekings 2008). It was also of course a pact specifically to enshrine white domination: it would invest in the wellbeing, modernisation and moral upliftment of white working class families, but Africans especially rural Africans - would not benefit (Seekings and Nattrass 2005). In the racialized biopolitics of the emerging South African welfare state, rural African life was simply not included within the definition of the social (Ferguson 2012). This segmentation of the population went hand in hand with the development of an elaborate form of 'bifurcated government' that incorporated rural black South Africans not as potential citizens but as the subjects of traditional leaders in communal areas, and a policy of Native Administration that was specifically concerned to limit the extent of African urbanization (Mamdani 1996; Hickel 2015; Breckenridge 2008).

An important aspect of this history is the role, throughout the twentieth century, of the agrarian economies and social systems of the 'Native Reserves' as bulwarks against (and refuges from) processes of commodification. While agricultural productivity in the former homelands declined in its contribution to the formal economy, it continued to play a significant role in household survival strategies (Adams, Cousins, and Manona 2000). Natural resource collection too made an important and possibly underestimated contribution (Shackleton, Shackleton, and Cousins 2002). But as important was the role of social reproduction and 'distributive labour' (Ferguson 2015; Cousins et al. 2017). Land mattered, not just as a factor of production, but also as a place to live, as political terrain, and (crucially) as territorial basis for the sustenance of the social networks and familial relations that underpinned the informal production of social welfare (Davy 2009; Ferguson 2012, 2013; Hickel 2015).

These considerations loomed large in debates about the nature and boundaries of the South African distributive regime. Throughout the twentieth century the exclusion of most Africans from formal welfare provision depended on the explicit assumption that they could rely on subsistence agriculture and the solidarities of rural family life. In fact, officials argued explicitly that assuming state responsibility for indigent Africans would undermine the integrity of the social structures and cultures of 'the Bantu People' (M. Du Toit 2014). The utility of the reserve economy thus did not only lie in the extent to which it made possible a rural subsidy to the wages of migrant workers (Wolpe 1972): the agrarian economy and informal networks of rural society also had central importance as sites of welfare production and 'distributive labour' (Ferguson 2015).

These strategies also meant that large segments of South Africa's subaltern populations lay beyond the purview of governmental knowledge. As Keith Breckenridge has shown, the ability of colonial governments to rely on the co-opted structures of customary rule had created a tradition of 'power without knowledge': although poor black South Africans had long been fiscally incorporated as payers of tax (Ndlovu 2017), systems of native administration had been characterised by a resolute refusal to take governmental 
responsibility for their development - or even very much interests in their conditions of life (Breckenridge 2008; Ferguson 2012). Despite its intrusive and authoritarian ambitions the Apartheid government failed to 'seize hold' of African populations beyond the aggregate level. Attempts to use fingerprint systems and passbooks to create reliable records that could be reliably used for central identification and control of individuals largely failed. Verwoerd's attempts to use biometric measures to create a centralized system for the policing of the African population came to naught, and had to be replaced by deepening the state's reliance on traditional leaders (Breckenridge 2014b) Similar considerations informed the segregation of urban space: Jenny Robinson argues that the relegation of black South Africans to 'locations' situated on the urban edge was employed 'as a means of governing non-disciplined, non-consenting populations who proved difficult to observe and to record, making the implementation of specific policies an insurmountable task' (Robinson 1997, 366; see also Chari 2010)

These boundaries were however unstable from the beginning. Even in the 1940s, it was already clear that significant numbers of African people were settling in the cities, requiring their piecemeal incorporation within official understandings of sociality and modernity (Ferguson 2012). In fact, it could be argued that the rise to power of the National Party occurred partly in response to the perceived implications of the growing inevitability of African de-agrarianization. In the context of the competing policy narratives of the $1940 \mathrm{~s}$ and the very different 'worlds of possibility' they invoked (Dubow and Jeeves 2005), Apartheid policy was in part a forceful re-assertion of the exclusion of Africans, the primacy of bifurcated government and a recommitment to strategies of rural containment, if not outright 're-agrarianization' (Ferguson 2012).

But the ongoing collapse of the Bantustan economies as sites of welfare production meant that rural containment could not succeed. Apartheid's own policies had doomed it from the start. St J Page Yako's poem on The Contraction and Enclosure of the Land captures it precisely: the blanket of the land could no longer protect the people who had depended on it, or sustain the social relations that allowed mutuality and care. From now on they would be enfolded within a different order: one in which oxen would give way to pieces of paper, and in which their wellbeing would depend on 'coins that come and go.'3 As the 1970s dawned, it became increasingly obvious that the progressive inclusion of black South Africans into the capitalist socio-economic order also meant that the terms of bifurcated government would have to be revised. The systematically racist biopolitics of early Apartheid gave way to more ad hoc strategies aimed at maintaining white rule while making concessions to the political incorporation of black populations. As more African people acquired the limited rights of urban residence afforded by Apartheid legislation and as popular mobilisation and resistance took hold - government started for the first time to engage with them as political subjects, explicitly framing the reality of black urbanisation (and the perceptions, aspirations and subjectivity of 'the urban Black man') as objects of empirical concern and governmental management (Von Schnitzler 2016, 56-

\footnotetext{
${ }^{3}$ For an alternative reading of the poem, see (Krog 2015).
} 
63). By 1984 it had adopted a Population Development Programme aimed at accelerating the social and economic development of 'all population groups' - albeit with a racially differentiated framework that still emphasised controlled urbanisation, 'orderly geographic distribution' and the development of the population in the rural areas (Klugman 1991; Chimere-Dan 1993).

In the context of rising popular protest and the increasing contradictions within the Apartheid economy, however, these trends could not be finessed. With the blanket of the land in tatters, rural containment had failed utterly. The future of black South Africa was in the cities. The new political order inaugurated with the transition to democracy was explicitly based on the notion that South African belonged to 'all who live in it' (Republic of South Africa 1996) - and this implied not only the extension of the formal rights of citizenship but also a radical and universalist commitment to full biopolitical inclusion.

\section{Agrarian transition and post-Apartheid biopolitics}

This suggests some interesting questions with which to approach both the continuities and the ruptures of the democratic transition. What was the extent - and what were the limitations - of inclusion in the South African distributional regime? Who was to be incorporated within it, on what terms, and to what effect? What underlying political rationalities - what conceptions of the social, what forms of administrative deliberation, what systematic bodies of knowledge and expertise - were involved in these decisions and their implementation? More specifically, how can these help illuminate our understanding of the consequences and the implications of South Africa's 'stalled agrarian transition'? What are the specific challenges posed for the arts of government by the realities created by the path of capitalist development in South Africa? And how does that alter our understanding of the limits and possibilities, not only of agrarian reform, but of social and political change more generally?

Clearly this is an enormous and complex field of study, not least because the processes whereby the South African population was enfolded within the matrices of pastoral power have been uneven, and followed different courses in different domains of government. The configurations of 'pastoral' and 'disciplinary' power, the stakes and outcomes of social and political struggle, the nature of biopolitical segmentation, and the forms of political deliberation that were deployed in relation to (for example) rural poverty, unemployment and the informal sector were different from those that characterised other terrains such as those of public health, policing, water provision or education. Totalising formulations and sweeping generalisations are likely to be misleading: instead one should should attend to the detailed history of particular moments in the development of the South African arts of government as they unfolded in different contexts.

The pages that follow focus on those developments most clearly related to the distributional implications of agrarian restructuring. For the purposes of this discussion, four domains are particularly significant: firstly, the economic incorporation of poor rural people as workers and consumers within the distributional regime; secondly, the 
formulation and implementation of an ambitious suite of 'make live' policies aimed at investing in their well-being and productivity; thirdly, the discursive reconstruction of poverty and poor populations as objects of scientific knowledge and managerial intervention; and finally the development of a technical politics of population management . Much important work has been done here, particularly by Seekings \& Nattrass, Breckenridge, Ferguson, Von Schnitzler and others. The chief focus of this paper is to connect these insights with questions of agrarian transition and to sketch out implications for policy and for further research.

Firstly, while the turn to full biopolitical incorporation marked a significant rupture from earlier periods, the end of Apartheid did not involve a thoroughgoing transformation of the distributional regime. Rather, as Seekings and Nattrass have argued, it led to its reform and deracialization: all South Africans, black and white, rural and urban, would be included within the provisions of a deal similar to that hammered out for white workers in the 1920 s and 1930s (Seekings and Nattrass 2005; Lund 2009). Crucially, policies for development and growth were dominated by high-modernist, 'productionist' assumptions that linked social citizenship to participation in the productive economy (Barchiesi 2011; Ferguson 2015). On the 'left', this involved classically Marshallian proposals for social democratic incorporation on the basis of the 'citizen-worker nexus'; on the 'right' the emphasis was on 'enterprising citizenship' within the informal economy. But both visions were premised on the assumption that the realisation of socio-economic rights would depend on employment creation, productivity gains, and integration into the global economy (Nattrass 2001; Gelb 2003).

Secondly, this productionist biopolitics resulted in a programme of liberalisation and global economic integration that involved both processes of intensified capitalist transformation and processes of decommodification. Conformity with neoliberal macroeconomic discipline was pursued alongside enormous expenditure on health, education and social development (Seekings and Nattrass 2015). Crucially, while welfare spending and social security did not initially feature centrally in the ANC's Reconstruction and Development programme, a series of somewhat fortuitous and improvisatory interventions in the reform of pensions in the then Bantustan of KwaZulu laid the groundwork for the roll out of a non-contributory social grant system that today is the mainstay of South Africa's social protection systems (Lund 2008; Breckenridge 2014b). The extent and ambition of these interventions give the lie to any notion that South African policy makers simply capitulated to 'neoliberal orthodoxy' (Habib and Padayachee 2000; Magubane 2002; Peet 2002; Ansari 2017). Rather, post-Apartheid social and economic policy is probably best understood as an heterogenous mix of neoliberal and social democratic measures, combined within a political project that is nationalist rather than liberal in character (Ivor Chipkin 2007; Reddy 2015; Seekings and Nattrass 2015).

Thirdly, the shift to a society founded on the promise of radical, universalist, egalitarian biopolitical inclusion involved much more than a change in distributional arrangements. It required changes in the way in which government operated and in the kinds of 
deliberation and decision-making required from its office-bearers. Poverty itself had to be made governable: this meant finding ways to make poverty and vulnerability visible to the organs of the state, and to construct poor populations as objects of technical knowledge and managerial intervention (Scott 1998). Obviously this required a massive explosion in the extent and ambit of (chiefly quantitative) empirical knowledge (Seekings 2001). At the same time, it also involved a distinctive politics of knowledge production and what Bruno Latour and his students would call 'discursive seclusion' (Callon, Lascoumes, and Barthe 2011): the definition of social and political problems and the specification of valid evidence were subject to tight disciplinary control, with economic and health sciences being given pride of place. Policy deliberation increasingly happened in closed forums, removed from public visibility and insulated from participation, while key social and political problematics were defined as the prerogative of appointed officials and certified experts.

But the growth of 'poverty knowledge' and the academic industries on which it depended was only part of a much larger (although patchy and piecemeal) meta-political project - a project not so much of 'the conduct of conduct' as of 'the government of government' aimed at the re-organisation of the organs of government themselves as deliberative institutions. These processes are much less well understood and merit further investigation. One important and influential intervention has been the dissemination of normative doctrines of 'evidence-based policy making' in key ministries (Du Toit 2012). While largely framed in the language of 'capacity building' these took shape, in terms of their explicit aims, chiefly as a series of disciplinary interventions into the forms and content of policy deliberation within the state. Also needing much more research attention is the development of technocratic, top-down and indicator based forms of trans-scalar 'monitoring and evaluation' that sought to make not only the impacts of state programming, but also the working of the state itself visible, knowable and legible (Mueller-Hirth 2012; Abrahams 2015).

Fourthly, the collapse of 'rural containment' and the rapid growth of mobile, vulnerable and unruly populations of poor urban people also encouraged the development of what Antina von Schnitzler (Von Schnitzler 2013, 2016) has dubbed a 'technical politics' of population management. Here, as von Schnitzler has shown in her analysis of contests around the installation of pre-paid water meters, post-Apartheid arts of government show important continuities with the strategies developed in the 1970 s and 1980 os for dealing with contentious popular politics by displacing them onto technical terrain, often in ways that were heavily dependent on infrastructural innovation. While, under Apartheid, pre-paid water meters were seen as a way of forestalling the mobilising tactics of activists seeking to question the legitimacy of Black Local Authorities, the roll-out of such devices in post-apartheid South Africa formed part of a pedagogical social practice, seeking to inculcate 'responsible' forms of citizenship and thereby to normalize the fraught relationship between urban government and impoverished urban residents.

By and large, these strategies of economic and political inclusion have had only limited success in containing the consequences of the collapse of the agrarian economy of the 
reserves. Firstly, the growth path of the South African economy, characterised by high degrees of financialisation, the predominance of the 'minerals-energy complex', significant capital intensity, corporate concentration and vertical integration and low degrees of labour absorptivity, failed to provide the employment opportunities needed by impoverished, displaced and landless South Africans. That vision of growth had depended on highly normative conceptualisations of the place to be occupied by poor African people (as modern, productive workers; as innovative, dynamic farmers; as resilient urban entrepreneurs) that had little to do with the real structures of need, opportunity or possibility on offer. Instead, processes of biopolitical segmentation and differential incorporation continued, and the divisions between the socio-economic 'insiders' and 'outsiders' that characterised late Apartheid were exacerbated (Seekings and Nattrass 2005). Crucially, far from reversing Apartheid land dispossessions, post-Apartheid economic, economic and agricultural policy simply exacerbated the rapid consolidation of corporate control (Bernstein 2013), undermining the prospects of land reform and encouraging rural jobshedding. At the same time, urban jobs went into decline. Instead of social inclusion, South Africa's post-Apartheid growth path resulted in processes of 'jobless deagrarianisation' that rendered poor populations dependent on the market economy while undermining their agency as workers, farmers, traders and producers ( $\mathrm{Du}$ Toit and Neves 2014). Thus, at the very moment of the final collapse of any dream of re-agrarianisation, the prospect of finding prosperity in the urban economy also appeared to disappear into thin air. As Ferguson observes, both of the 'great fantasies of familism' that had sustained policy makers' bifurcated visions of South African sociality in the twentieth century - that of the rural kinship network, sustained by agricultural production and that of the urban nuclear family, constellated around the male breadwinner - were thus brought to 'an abrupt and more or less simultaneous end' (Ferguson 2012, 508).

Policy makers have only unevenly adjusted to these changes. On the one hand, the design of the Child Support Grant has proved to be sensitive to social realities, emphasising the need to 'follow the child' rather than to impose unrealistic assumptions about the coherence of family life (Lund 2012). On the other hand social protection measures for adults are still based on the fiction of full employment, so that large numbers of unemployed poor black South Africans (in particular, working age, able-bodied men) are excluded from their ambit (Seekings and Nattrass 2005; Marais 2011). The harshest form of biopolitical segmentation, however, was that involved in the Mbeki regime's long refusal to contemplate the state-funded extension of anti-retroviral therapy, so that treatment for HIV and AIDS could for most South Africans only be accessed through the private sector - a biopolitics of abandonment that has been estimated to result in the loss of 2,65 million disability-adjusted life years (Marais 2005; Fassin 2007; Johnson et al. 2017).

The institutions of government themselves have been similarly subject to crisis. Again, the point is not that hopes of a 'developmental state' were subverted by the orthodoxies of 'neoliberal rule'. Rather, it seems that the intersection of multiple, often incompatible or poorly aligned rationalities of rule - nationalist class formation and neoliberal reason; dirigiste statism and 'new public management'; 'evidence based policy' and political 
patronage - produced increasing levels of dysfunctionality. The effect was not so much to promote 'the conduct of conduct' as to create a crisis of governability within the state (Von Holdt 2010; I. Chipkin and Lipietz 2012; Ivor Chipkin 2013; Public Affairs Research Institute 2014). In addition, the centrality of the traditions of popular struggle upon which the political authority of the ruling party has been built meant that the 'rendering technical' of complex and contested questions of distributional justice was only ever partially successful. The relationship between the 'secluded spaces' of policy deliberation and the popular forums where the legitimacy of those policies were questioned was constantly contested (Davie 2015). Similarly, attempts to normalize the relationship between local government and township populations through the imposition of infrastructural solutions (Von Schnitzler 2016) was constantly undermined by the politics of an insurgent citizenship that insistently made its political demands on public terrain (Von Holdt et al. 2011).

A key task for agrarian scholarship in South Africa today is to understand the complex and heterogeneous nature of the liminal landscapes - simultaneously post-agrarian and postindustrial - that have been created by these uneven processes of capitalist incorporation, and to explore how these have been governed. Crucially, there is no sense in which it is any more possible to speak of a separate agrarian or reserve economy in South Africa. This is the reality missed by 'second economy' discourse: even the most distant rural districts are thoroughly connected to the agro-food systems and markets of the core economy by spatially extended value chains and rural-urban connections (Du Toit 2004; Philip 2010; $\mathrm{Du}$ Toit and Neves 2014; Neves and Hakizimana 2015). The livelihood strategies and coping mechanisms of poor African households themselves also cut across the ruralurban divide. These strategies have long involved the reliance on diverse livelihood portfolios and spatially extensive networks of kinship and support that traverse rural and urban spaces ( $\mathrm{Du}$ Toit and Neves 2008). But while these systems of survivalist improvisation are often inventive and resilient, they are also in crisis. Not only is smallholder agriculture itself under pressure; the forms of social reproduction on which poor black South Africans rely for the provision of informal social protection are themselves no longer sustainable (Cousins et al. 2017 in this volume). Uncertain employment, the requirements of urban consumption and a predatory micro-lending industry have contributed to the demise of what Keith Breckenridge has called 'the impossible fantasy of the viable rural homestead' (Breckenridge 2014a). Partly as a result of this, the former homelands have continued to be zones of vulnerability and poverty, doing significantly worse than the rest of South Africa on a variety of indicators of deprivation (Noble and Wright 2013). Those displaced from farms and communal lands live in marginalised spatial poverty traps at the fringes of the South African urban landscape order: peri-urban shanty-towns or rural dumping sites where they try to stitch together fragmented and diverse livelihood activities into a barely adequate living (Neves and Du Toit 2016). These 'grey spaces' of South African modernity perpetuate and reconfigure the bifurcated territoriality of Apartheid's spatial ordering: they are marginalized zones of black life adversely incorporated within South Africa's formally non-racial order (Hickey and Du Toit 2007). Straddling urban and rural economies, they are the backwaters of a 
'proletariat that scratches about on the land' (Murray 2009) dependent on both the metropolitan 'centre' and the rural 'periphery,' but profiting from neither. Particularly important is the need to understand the interactions between governmental institutions and poor and marginalised populations in these contexts: indications are that the governmental regimes and planning approaches deployed in township economies have proved to be poorly suited to the tenurial needs and the fluid livelihood strategies of a still very mobile African population, often exacerbating regulatory exclusion (Charman, Govender, and De Villiers 2017) and entrenching political marginalisation (De Satgé and Watson 2018).

While the 'citizen-worker nexus' has failed to provide an effective base for the realisation of universal socio-economic rights, the most robust modes of biopolitical integration seem to be coming from two very different directions. One can be found by attending to the materiality of the technologies accompanying the expansion of the welfare system. Breckenridge has shown how the processes of institutional integration on which biopolitical inclusion depends have been spearheaded by the involvement of private sector companies such as Net1, Cash Paymaster Services and Grindrod Bank, and have been shaped by policy frameworks emphasising the need for 'financial deepening' and the inclusion of the unbanked poor (Ardington et al. 2004; Hurwitz and Luiz 2007; Breckenridge 2014b). As a result access to social grants has been at the cost of unprotected inclusion into a predatory market in loans and financial services (Carel 2014). Salaries and social grant payments, instead of reaching targeted groups are recycled back to corporate South Africa (James 2014). Perhaps the most effective and far-reaching form of inclusion within the South African distributive regime is not the 'enterprising' citizen or the prudent, improving worker, but the debtor-beneficiary (Du Toit 2017).

Intersecting with these processes of financial inclusion through the welfare system, a second and rather more obscure project is taking shape: the re-introduction of some of the strategies that characterized Apartheid governmentality. In the rural areas, the most remarkable development has been the reassertion of authoritarian versions of customary power, reinscribing the architecture of bifurcated government within the constitutional order of post-Apartheid South Africa. One important consequence has been the facilitation of processes of elite capture and resource extraction (Cousins and Claassens 2008; Mnwana 2011; Buthelezi and Gould 2014; Peires 2014; De Souza 2014). But more is at stake here: as more nuanced anthropological work on the persistence of customary rule throughout Africa has shown, much work remains to be done to understand the complex ways in which these structures are engaging with - and transforming - the meanings of democracy and political modernity (Buthelezi and Skosana 2018; Comaroff and Comaroff 2018).

\section{Conclusion}

A remarkable feature of the 'land debate' in South Africa is the way in which it is presented, in popular discourse, as at one and the same time tangential and inescapable. In the mainstream media, land reform is often framed within a conceptual bubble disconnected from 
the realities of modern urban life: a matter of 'righting the wrongs of the past,' meaningful only to the groupings (land owners, 'chiefs' and farmers; rural tenants, farm workers and people living on communal land) whose rights to land are to be affected. Described in these terms, it is seen to be only indirectly relevant those not actually dwelling on 'the land': significant either because of the threat posed to the political legitimacy of the postApartheid order (e.g. by the 'time bomb' of racially skewed landownership figures) or because of the danger that redistributing productive land supposedly poses to urban food security. Yet set up in those terms, land reform also appears an insoluble problem, destined to return, implacably, like some kind of ineradicable and constitutive political original sin.

Consider these impasses from the point of view afforded by an analysis of South Africa's stalled agrarian transition and its biopolitical reverberations. Far from being a matter of rural development and agricultural productivity, the implications of jobless deagrarianisation are everywhere present in the post-agrarian landscapes occupied by South Africa's displaced precariat. Crucially, African poverty and racial inequality are not simply the historical results of Apartheid dispossession. Firstly, landlessness is a condition exacerbated and consolidated by the normal course of capitalist development both during and after Apartheid - a path of development that has pivoted,as Henry Bernstein has insisted, on the decisive resolution of the agrarian question of capital in the interests of capital (Bernstein 2007). Secondly, landlessness is only a necessary, not a sufficient, cause of present day precarity. Its other determinants lie in the failure of post-Apartheid biopolitics to offer sustainable forms of urban incorporation. Dominant policy proposals for the scope and direction of land reform tend to fail almost entirely in addressing these realities: not only are their stated aims - an invigorated class of black capitalist farmers, a 'vibrant' rural economy, paths to prosperity for enterprising smallholders practically unachievable; they also fail to address the pressing needs and concerns of South Africa's landless poor.

It is in this context that the politics of land reform have returned to haunt South Africa surging from the margins to become a central question of national politics. In these debates, land features not as a factor of production or even a mainstay of survivalist livelihoods and informal safety nets, but as a political signifier; a symbol of the violated black body of a thwarted nation (Ivor Chipkin 2002, 2016). In these discussions the increasingly evident failure of attempts to redistribute commercial agricultural farming land to black South Africans are symbolic of a much more broadly located sense of economic marginalisation and political frustration. Ownership of the lion's share of farmland by white farmers and large corporates is a matter not simply of the relations of agricultural production but political shorthand for a wide range of unresolved questions relating to the the presumed dominance of 'white monopoly capital,' unchallenged white privilege and the legitimacy of the post-Apartheid racial and social order itself. And the political meaning of the demand for 'expropriation without compensation' lies, not in any calculus around the viability of land reform per se, but as a performative demand for the symbolic recognition 
of the prior political rights of South Africa's indigenous people and their descendants (Du Toit 2018).

This raises urgent questions for the research and theoretical agenda of an enquiry into post-Apartheid biopolitics. One of the most arresting features of much of the Foucauldian literature has been its abiding functionalism: as if the techniques of modern power can be fully grasped through an analysis of their specifically technical efficacy; as if the 'calculative rationality' of neoliberal arts of government have simply displaced the possibilities of public politics and democratic contestation. But as the South African example fulsomely shows, the arts of government involve not only the resources of technical, administrative and bureaucratic reason but also the contestation of political hegemony. The most serious implications of the failure of biopolitical incorporation do not only lie in the dire consequences for poor and marginalised people. They cast into question the very meaning of citizenship and the value of the project of democracy itself. If the blanket of the land and the agrarian order it supported no longer enfolds those who first lived on it, what sorts of political community are possible at all? That is the question Yako's poem poses to South Africa today.

\section{Acknowledgements}

An earlier version of this paper was presented at the BICAS international conference Rural Transformations and Food Systems - The BRICS and Agrarian Change in the Global South on 20-21 April 2015 at the University of the Western Cape. Key points have also been recapitulated in Development and Change (Du Toit 2017). As usual, my intellectual debts are many and various, and too large to be paid back in either coins or land. Most of the arguments set out here come from what I have learned Henry Bernstein, Grace Davie, Jim Ferguson, Keith Hart, Francie Lund, David Neves, Michael Noble, Jeremy Seekings and Gemma Wright. Any original ideas found here may safely be credited to them; this paper mainly connects the dots. Thanks are also due to Lynette Maart, Patrick Cairns, Craig McKyne, Erin Torkelson and David Carel, who helped me understand the activities of Cambist, Net1, Grindrod Bank and CPS. I am also indebted to the anonymous reviewers of the paper, who contributed greatly to whatever rigour and coherence it has.

\section{Disclosure statement}

No potential conflict of interest was reported by the author.

\section{Notes on contributor}

Andries du Toit is the Director of the Institute for Poverty, Land and Agrarian Studies at the University of the Western Cape in South Africa. His research interests include the social relations of production in commercial agriculture, the dynamics of structural poverty and inequality, and the political formations of neoliberal governmentality and democracy in contexts of agrarian change. Email: adutoit@plaas.org.za

\section{ORCID}

Andries du Toit http://orcid.org/0000-0001-5845-0774 


\section{References}

Abrahams, Mark A. 2015. "A Review of the Growth of Monitoring and Evaluation in South Africa: Monitoring and Evaluation as a Profession, an Industry and a Governance Tool.” African Evaluation Journal 3 (1): 1-8.

Adams, Martin, Ben Cousins, and Siyabulela Manona. 2000. "Land Tenure and Economic Development in Rural South Africa: Constraints and Opportunities." In At the Crossroads: Land and Agrarian Reform in South Africa into the 21st Century, edited by Ben Cousins, 111-128. Bellville: Programme for Land and Agrarian Studies.

Agamben, G. 1998. Homo Sacer: Sovereign Power and Bare Life. Stanford: Stanford University Press. Ansari, Shaukat. 2017. "The Neo-Liberal Incentive Structure and the Absence of the Developmental State in Post-Apartheid South Africa." African Affairs 116 (463): 206-232.

Ardington, Cally, David Lam, Murray Leibbrandt, and James Levinsohn. 2004. "Savings, Insurance and Debt over the Post-Apartheid Period: A Review of Recent Research." Working Paper. CSSR and SALDRU.

Barchiesi, Franco. 2011. Precarious Liberation: Workers, the State, and Contested Social Citizenship in Postapartheid South Africa. New York: SUNY Press.

Barnett, Clive. 2005. "The Consolations of 'Neoliberalism." Geoforum 36 (1): 7-12.

Barnett, Clive. 2010. "Publics and Markets: What's Wrong with Neoliberalism?" In The Sage Handbook of Social Geography, edited by Susan J. Smith, Rachel Pain, Sallie A. Marston, and John Paul Jones III, 269-296. London: Sage.

Barnett, Clive. 2017. The Priority of Injustice: Locating Democracy in Critical Theory. Athens: University of Georgia Press.

Bernstein, Henry. 2006. "Is There an Agrarian Question in the 21st Century?" Canadian Journal of Development Studies 27 (4): 449-460.

Bernstein, Henry. 2007. "Agrarian Questions of Capital and Labour: Some Theory about Land Reform (and a Periodisation)." In The Land Question in South Africa: The Challenge of Transformation and Redistribution, edited by Lungisile Ntsebeza, and Ruth Hall, 27-59. Cape Town: Human Sciences Research Council.

Bernstein, Henry. 2013. "Commercial Agriculture in South Africa since 1994: "Natural, Simply Capitalism." Journal of Agrarian Change 13 (1): 23-46.

Bénit-Gbaffou, Claire. 2018. "Unpacking State Practices in City-Making, in Conversations with Ananya Roy." The Journal of Development Studies o (o): 1-10.

Bolwig, A., S. Ponte, A. Du Toit, L. Riisgaard, and N. Halberg. 2010. "Integrating Poverty and Environmental Concerns into Value Chain Analysis: A Conceptual Framework." Development Policy Review 28 (2): 173-194.

Bracking, Sarah. 2003. The Political Economy of Chronic Poverty. SSRN Scholarly Paper ID 1754446. Rochester, NY: Social Science Research Network.

Breckenridge, Keith. 2008. "Power without Knowledge: Three Nineteenth Century Colonialisms in South Africa." Journal of Natal and Zulu History 26: 3-30.

Breckenridge, Keith. 2014a. "Marikana and the Limits of Biopolitics: Themes in the Recent Scholarship of South African Mining." Africa 84 (01): 151-161.

Breckenridge, Keith. 2014b. Biometric State. Cambridge: Cambridge University Press. 
Buthelezi, Mbogiseni, and Chandré Gould. 2014. "Accessing Land and Capital in Rural South Africa - New Forms of Old Power." SA Crime Quarterly, no. 49: 3-5.

Buthelezi, Mbogiseni, and Dineo Skosana. 2018. "The Salience of Chiefs in Postapartheid South Africa: Reflections on the Nhlapo Commission." In The Politics of Custom: Chiefship, Capital, and the State in Contemporary Africa, edited by John L. Comaroff, and Jean Comaroff, 110-133. Chicago: University of Chicago Press.

Callon, Michel, Pierre Lascoumes, and Yannick Barthe. 2011. Acting in an Uncertain World: An Essay on Technical Democracy. Translated by Graham Burchell. Cambridge: The MIT Press.

Carel, David. 2014. "Greed, Inc: Making Millions off the Country's Poorest." The Daily Maverick (blog). 2014. http://www.dailymaverick.co.za/opinionista/2014-12-10greed-inc-making-millions-off-the- countrys-poorest\#.VR1aQDuUeyQ.

CDE. 2006. "Accelerating Shared Growth: Making Markets Work for the Poor in South Africa." The ComMark Trust; The Centre for Development and Enterprise.

Chari, Sharad. 2010. "State Racism and Biopolitical Struggle: The Evasive Commons in Twentieth-Century Durban, South Africa." Radical History Review 2010 (108): 7390.

Charman, Andrew, Thireshen Govender, and Sarah De Villiers. 2017. The Impact of Land Stems on Micro-Economic Investments. Cape Town: Sustainable Livelihoods Foundation.

Chatterjee, Partha. 2006. The Politics of the Governed: Reflections on Popular Politics in Most of the World. Leonard Hastings Schoff Lectures. New York: Columbia University Press.

Chimere-Dan, Orieji. 1993. "Population Policy in South Africa." Studies in Family Planning 24 (1): 31-39.

Chipkin, Ivor. 2002. "The Sublime Object of Blackness." Cahiers d'études Africaines 42 (167): 569-584. Chipkin, Ivor. 2007. Do South Africans Exist?: Nationalism, Democracy and the Identity of "the People". 1st ed. Johannesburg: Wits University Press.

Chipkin, Ivor. 2013. "Whither the State? Corruption, Institutions and State-Building in South Africa." Politikon 40 (2): 211-231. doi:10.1080/02589346.2013.798457.

Chipkin, Ivor. 2016. "The Decline of African Nationalism and the State of South Africa." Journal of Southern African Studies 42 (2): 215-227.

Chipkin, I., and B. Lipietz. 2012. "Transforming South Africa's Racial Bureaucracy: New Public Management and Public Sector Reform in Contemporary South Africa.” 1. PARI Long Essays. Public Affairs Research Institute.

Clarke, John. 2008. "Living with/in and without Neo-Liberalism." Focaal 51: 135-147.

Collier, Stephen J. 2009. "Topologies of Power: Foucault's Analysis of Political Government beyond 'Governmentality.”' Theory, Culture \& Society 26 (6): 78-108.

Collier, Stephen J. 2011. Post-Soviet Social: Neoliberalism, Social Modernity, Biopolitics. Princeton, NJ: Princeton University Press.

Comaroff, John L., and Jean Comaroff. 2018. "Chiefs, Capital and the State in Contemporary Africa: An Introduction.” In The Politics of Custom: Chiefship, Capital, and the State 
in Contemporary Africa, edited by John L. Comaroff, and Jean Comaroff, 1-48. Chicago: University of Chicago Press.

Cousins, Ben. 2013. "Smallholder Irrigation Schemes, Agrarian Reform and 'Accumulation from Above and from Below' in South Africa." Journal of Agrarian Change 13 (1): 116-139.

Cousins, Ben. 2015. "Through a Glass Darkly: Towards Agrarian Reform in South Africa." In Land Divided, Land Restored: Land Reform in South Africa for the 21st Century, edited by Cherryl Walker and Ben Cousins, 250-269. Auckland Park: Jacana.

Cousins, Ben, and Aninka Claassens, eds. 2008. Land, Power \& Custom: Controversies Generated by South Africa's Communal Land Rights Act. Cape Town: Juta and Company.

Cousins, Ben, Alex Dubb, Donna Hornby, and Farai Mtero. 2017. "Social Reproduction of 'Classes of Labour' in Rural Areas of the Global South: Contradictions, Contestations and Politics." Unpublished typescript.

Davie, Grace. 2015. Poverty Knowledge in South Africa: A Social History of Human Science, 1855-2005. New York: Cambridge University Press.

Davy, Benjamin. 2009. "Centenary Paper: The Poor and the Land: Poverty, Property, Planning." Town Planning Review 80 (3): 227-265.

Davy, Benjamin, Ulrike Davy, and Lutz Leisering. 2013. "The Global, the Social and Rights. New Perspectives on Social Citizenship." International Journal of Social Welfare 22: S1-S14.

De Satgé, Richard, and Vanessa Watson. 2018. Urban Planning in the Global South: Conflicting Rationalities in Contested Urban Space. Cham: Springer.

De Soto, Hernando. 2010. The Mystery of Capital: Why Capitalism Triumphs in the West and Fails Everywhere Else. New ed. London: Transworld Digital.

De Souza, Monica. 2014. "Justice and Legitimacy Hindered by Uncertainty: The Legal Status of Traditional Councils in North West Province 1." South African Crime Quarterly 49 (1): 41-56.

Donzelot, Jacques. 1988. "The Promotion of the Social." Economy and Society 17 (3): 395427. Donzelot, Jacques. 1997. The Policing of Families. Baltimore: The Johns Hopkins University Press.

Du Toit, Marijke. 1996. "Women, Welfare and the Nurturing of Afrikaner Nationalism: A Social History of the Afrikaanse Christelike Vroue Vereniging, c.1870-1939." Thesis, University of Cape Town.

Du Toit, Andries. 2004. "Social Exclusion' Discourse and Chronic Poverty: A South African Case Study." Development and Change 35 (5): 987-1010.

Du Toit, Andries. 2012. "Making Sense of 'Evidence': Notes on the Discursive Politics of Research and Pro-Poor Policy Making." Working Paper 21. PLAAS Working Papers.

Du Toit, Marijke. 2014. "The State, Ubuntu and the 'Civilised' Black Poor: The Racialised Provision of Child Maintenance Grants in South Africa, 1921-1940.” Presented at the WISER Seminar, Johannesburg, October 20.

Du Toit, Andries. 2017. "Post-Agrarian Biopolitics." Development and Change 48 (6): n/an/a. 
Du Toit, Andries. 2018. "The Land Question Is also about Political Belonging." Daily Maverick. August 27, 2018. https://www.dailymaverick.co.za/article/2018-o8-27the-land-question-is-also-about- political-belonging/.

Du Toit, Andries, and David Neves. 2007. "In Search of South Africa's Second Economy." Africanus 37 (2): 145-174.

Du Toit, Andries, and D. Neves. 2008. "Informal Social Protection in Post-Apartheid Migrant Networks: Vulnerability, Social Networks and Reciprocal Exchange in the Eastern and Western Cape, South Africa." 74. BWPI Working Paper. Brooks World Poverty Institute. http://www.bwpi.manchester.ac.uk/resources/Working-Papers/bwpi-wp7409.pdf.

Du Toit, Andries, and David Neves. 2014. "The Government of Poverty and the Arts of Survival: Mobile and Recombinant Strategies at the Margins of the South African Economy." The Journal of Peasant Studies 41 (5): 833-853.

Dubow, Saul, and Alan Jeeves. 2005. South Africa's 1940s: Worlds of Possibilities. Cape Town: Juta and Company.

Esping-Andersen, Gøsta. 1990. The Three Worlds of Welfare Capitalism. Princeton, NJ: Princeton University Press.

Fassin, Didier. 2007. When Bodies Remember: Experiences and Politics of AIDS in South Africa. Berkeley: University of California Press.

Ferguson, James. 2012. "What Comes After the Social? Historicizing the Future of Social Assistance and Identity Registration in Africa." In Registration and Recognition: Documenting the Person in World History, edited by Keith Breckenridge and Simon Szreter, 1st ed., 495-516. Oxford: Oxford University Press.

Ferguson, James. 2013. "How to Do Things with Land: A Distributive Perspective on Rural Livelihoods in Southern Africa." Journal of Agrarian Change 13 (1): 166-174.

Ferguson, James. 2015. Give a Man a Fish: Reflections on the New Politics of Distribution. Durham: Duke University Press Books.

Foucault, Michel. 1981. "Omnes et Singulatim: Towards a Criticism of Political Reason." The Tanner Lectures on Human Values 2: 223-254.

Foucault, Michel. 2003. Society Must Be Defended: Lectures at the College De France, 197576: Lectures at the Collaege De France, 1975-76. 1st ed. New York: Saint Martin's Press.

Foucault, Michel. 2007. Security, Territory, Population: Lectures at the Collège de France, 1977-78. Basingstoke: Palgrave Macmillan.

Foucault, Michel. 2008. The Birth of Biopolitics: Lectures at the Collège de France, 19781979. New York: Picador.

Gelb, Stephen. 2003. "Inequality in South Africa : Nature, Causes and Responses. DfID Policy Initiative on Addressing Inequality in Middle-Income Countries." The Edge Institute, no. November: $1 / 90$.

Gupta, Akhil. 2012. Red Tape: Bureaucracy, Structural Violence, and Poverty in India. Durham: Duke University Press.

Habib, Adam, and Vishnu Padayachee. 2000. "Economic Policy and Power Relations in South Africa's Transition to Democracy." World Development 28 (2): 245-263. 
Hall, Ruth, and Thembela Kepe. 2017. "Elite Capture and State Neglect: New Evidence on South Africa's Land Reform." Review of African Political Economy 44 (151): 122130.

Hickel, Jason. 2015. Democracy as Death: The Moral Order of Anti-Liberal Politics in South Africa. Oakland, CA: University of California Press.

Hickey, Sam, and Andries Du Toit. 2007. "Adverse Incorporation, Social Exclusion and Chronic Poverty." Working Paper 81. Chronic Poverty Research Centre Working Paper.

Hurwitz, Ingrid, and John Luiz. 2007. "Urban Working Class Credit Usage and OverIndebtedness in South Africa." Journal of Southern African Studies 33 (1): 107-131.

Iliffe, John. 1987. The African Poor: A History (African Studies Series, 58). Cambridge: Cambridge University Press.

James, Deborah. 2014. Money from Nothing: Indebtedness and Aspiration in South Africa. Stanford, CA: Stanford University Press.

Johnson, Leigh F., Margaret T. May, Rob E. Dorrington, Morna Cornell, Andrew Boulle, Matthias Egger, and Mary-Ann Davies. 2017. "Estimating the Impact of Antiretroviral Treatment on Adult Mortality Trends in South Africa: A Mathematical Modelling Study." PLoS Medicine 14 (12): e1002468.

Kavanagh, Robert, and Z. S. Qangule, trans. 1971. The Making of a Servant \& Other Poems Translated from Xhosa. Johannesburg: Ravan.

Klugman, Barbara. 1991. "Population Policy in South Africa: A Critical Perspective." Development Southern Africa 8 (1): 19-34.

Krog, Antjie. 2015. "Baas van Die PLAAS / Izwe Lethu: Essay in Fragments and Two Villanelles Exploring Different Relationships to Land in Some Indigenous Poetic Contexts." In Land Divided, Land Restored: Land Reform in South Africa for the 21st Century, edited by Ben Cousins, and Cherryl Walker, 206-231. Cape Town: Jacana.

Lemke, Thomas. 2002. "Foucault, Governmentality, and Critique." Rethinking Marxism 14: 49-64. Lemke, Thomas. 2004. "A Zone of Indistinction" - A Critique of Giorgio Agamben's Concept of Biopolitics. http://www.thomaslemkeweb.de/engl.texte/AZone3.pdf.

Li, Tania Murray. 2009. "To Make Live or Let Die? Rural Dispossession and the Protection of Surplus Populations." Antipode 41: 66-93.

Lund, Francie. 2008. Changing Social Policy: The Child Support Grant in South Africa. Cape Town: Human Sciences Research Council.

Lund, Francie. 2009. "Social Protection, Citizenship and the Employment Relationship." Working Paper 9. PLAAS Working Paper.

Lund, Francie. 2012. "Children, Citizenship and Child Support: The Child Support Grant in Post- Apartheid South Africa." In Registration and Recognition: Documenting the Person in World History, edited by Keith Breckenridge and Simon Szreter, 1st ed., 375-394. Oxford: Oxford University Press.

Magubane, Zine. 2002. "Globalization and the South African Transformation: The Impact on Social Policy." Africa Today 49 (4): 89-110.

Mamdani, Mahmood. 1996. Citizen and Subject: Contemporary Africa and the Legacy of Late Colonialism. Princeton: Princeton University Press. 
Marais, Hein. 2005. "Buckling: The Impact of AIDS in South Africa 2005." Centre for the Study of Aids, University of Pretoria.

Marais, Hein. 2011. South Africa Pushed to the Limit: The Political Economy of Change. London: Zed Books.

Marshall, T. H. 2009. "Citizenship and Social Class." In Inequality and Society, edited by Jeff Manza and Michael Sauder, 148-154. New York: W. W. Norton and Co.

Mbeki, Thabo. 2003. "Bold Steps to End the 'Two Nations' Divide." ANC Today 3 (33). http://www.anc. org.za/docs/anctoday/2003/at33.htm.

Miraftab, Faranak. 2004. "Neoliberalism and Casualization of Public Sector Services: The Case of Waste Collection Services in Cape Town, South Africa." International Journal of Urban and Regional Research 28 (4): 874-892.

Miraftab, Faranak. 2007. "Governing Post Apartheid Spatiality: Implementing City Improvement Districts in Cape Town.” Antipode 39 (4): 602-626.

Mnwana, Sonwabile Comfords. 2011. "Participation and Paradoxes: Community Control of Mineral Wealth in South Africa's Royal Bafokeng and Bakgatla Ba Kgafela Communities." PhD Thesis, University of Fort Hare.

Mueller-Hirth, Natascha. 2012. "If You Don't Count, You Don't Count: Monitoring and Evaluation in South African NGOs." Development and Change 43 (3): 649-670.

Murray, Colin. 2002. "Livelihoods Research: Transcending Boundaries of Time and Space." Journal of Southern African Studies 28 (3): 489-509.

Murray, Colin. 2009. Families Divided: The Impact of Migrant Labour in Lesotho. Reissue edition. London: Cambridge University Press.

Nattrass, Nicoli. 2001. "High Productivity Now: A Critical Review of South Africa's Growth Strategy." Transformation: Critical Perspectives on Southern Africa 45: 1-24.

Ndlovu, Tshatshisiwe. 2017. "Fiscal Histories of Sub-Saharan Africa: The Case of South Africa." 2. Working Paper. Johannesburg: Public Affairs Research Institute.

Neves, David, and Andries Du Toit. 2016. "The Penumbra of Employment: Impoverished Rural Livelihoods in South Africa." In Towards Employment-Intensive Growth in South Africa, 1st ed., 408. Cape Town: Juta UCT Press.

Neves, David, and Cyriaque Hakizimana. 2015. "Space, Markets and Employment in Agricultural Development: South Africa Country Report.” Research Report 47. Bellville: Institute for Poverty, Land and Agrarian Studies.

Noble, Michael, and Gemma Wright. 2013. "Using Indicators of Multiple Deprivation to Demonstrate the Spatial Legacy of Apartheid in South Africa." Social Indicators Research 112 (1): 187-201.

Oya, Carlos. 2009. "The World Development Report 2008: Inconsistencies, Silences, and the Myth of 'Win-Win' Scenarios.” Journal of Peasant Studies 36 (3): 593-601.

Palm, Kaylynn. 2018. "Expropriation of Land without Compensation Won't Solve Land Issues.” April 11, 2018. http://ewn.co.za/2018/04/11/expropriation-of-land-withoutcompensation-won-t-solve- land-issues.

Parnell, Susan, and Jennifer Robinson. 2012. "(Re)Theorizing Cities from the Global South: Looking Beyond Neoliberalism.” Urban Geography 33 (4): 593-617.

Peet, Richard. 2002. "Ideology, Discourse, and the Geography of Hegemony: From Socialist to Neoliberal Development in Postapartheid South Africa." Antipode 34 (1): 54-84. 
Peires, J. 2014. "History versus Customary Law: Commission on Traditional Leadership: Disputes and Claims." South African Crime Quarterly 49 (1): 7-20.

Pesek, Michael. 2010. "Foucault Hardly Came to Africa: Some Notes on Colonial and PostColonial Governmentality." In Entangled Histories: Reflecting on Coloniality and Postcoloniality, edited by Angelika Epple, Olaf Kaltmeier, and Ulrike Lindner, 4159. Leipzig: Leipziger Universitatsverlag.

Philip, Kate. 2010. "Inequality and Economic Marginalisation : How the Structure of the Economy Impacts on Opportunities on the Margins." Law, Democracy and Development 14: 1-28.

Prahalad, C. K. 2006. The Fortune at the Bottom of the Pyramid: Eradicating Poverty through Profits. 1st ed. Upper Saddle River, NJ: Wharton School Publishing.

Public Affairs Research Institute. 2014. "The Contract State: Outsourcing \& Decentralisation in Contemporary South Africa." Johannesburg. https://pari.org.za/contract-state/.

Reddy, Thiven. 2015. South Africa: Settler Colonialism and the Failures of Liberal Democracy. Uppsala: Zed Books.

Republic of South Africa. 1996. Constitution of the Republic of South Africa, 1996 (Act No. 108 of 1996). https://www.acts.co.za/constitution_of_/constitution_of_the_republic_o.

Republic of South Africa. 2015. 2015 Budget Policy Speech by Minister of Rural Development and Land Reform, Mr GE Nkwinti (MP). Department of Rural Development and Land Reform.

Revel, Judith. 2013. "Foucault and His 'Other': Subjectivation and Displacement." In The Biopolitics of Development: Reading Michel Foucault in the Postcolonial Present, edited by Sandro Mezzadra, Julian Reid, and Ranabir Samaddar, 15-24. London: Springer Science \& Business Media.

Robinson, Jennifer. 1997. "The Geopolitics of South African Cities: States, Citizens, Territory." Political Geography 16 (5): 365-386.

Roy, Ananya. 2009a. "Civic Governmentality: The Politics of Inclusion in Beirut and Mumbai." Antipode 41 (1): 159-179.

Roy, Ananya. 2009b. "Why India Cannot Plan Its Cities: Informality, Insurgence and the Idiom of Urbanization." Planning Theory 8 (1): 76-87.

Said, Edward W. 1979. Orientalism. 1st Vintage Books ed. New York: Vintage.

Samaddar, Ranabir. 2013. "Michel Foucault and Our Postcolonial Time." In The Biopolitics of Development: Reading Michel Foucault in the Postcolonial Present, edited by Sandro Mezzadra, Julian Reid, and Ranabir Samaddar, 25-44. London: Springer Science \& Business Media.

Scott, James C. 1998. Seeing Like a State: How Certain Schemes to Improve the Human Condition Have Failed. New Haven: Yale University Press.

Seekings, Jeremy. 2001. "The Uneven Development of Quantitative Social Science in South Africa." Social Dynamics 27 (1): 1-36.

Seekings, Jeremy. 2005. "Prospects for Basic Income in Developing Countries: A Comparative Analysis of Welfare Regimes in the South.” 104. CSSR Working Paper. Cape Town: Centre for Social Science Research, University of Cape Town. 
Seekings, Jeremy. 2008. "The Carnegie Commission and the Backlash against Welfare State-Building in South Africa, 1931-1937." Journal of Southern African Studies 34 (3): $515-537$.

Seekings, Jeremy, and Nicoli Nattrass. 2005. Class, Race, and Inequality in South Africa. New Haven: Yale University Press.

Seekings, Jeremy, and Nicoli Nattrass. 2015. Policy, Politics and Poverty in South Africa. 1st ed. Houndmills: Palgrave Macmillan.

Shackleton, Sheona, Charlie Shackleton, and Ben Cousins. 2002. "How Rich Is Our Land? Re-Valuing the Communal Areas of Southern Africa." Working Paper 62. Natural Resource Perspectives. ODI \& PLAAS.

Teppo, Annika Björnsdotter. 2004. The Making of a Good White: A Historical Ethnography of the Rehabilitation of Poor Whites in a Suburb of Cape Town. Helsinki: Helsinki University Press.

Von Holdt, Karl. 2010. "Nationalism Bureaucracy and the Developmental State: The South African Case." South African Review of Sociology 41 (1): 4-27.

Von Holdt, Karl, Malose Langa, Sepetla Molapo, Nomfundo Mogapi, Kindiza Ngubeni, Jacob Dlamini, and Adele Kirsten. 2011. The Smoke That Calls: Insurgent Citizenship, Collective Violence and the Struggle for a Place in the New South Africa. Johannesburg: Centre for the Study of Violence and Reconciliation; Society Work and Development Institute.

Von Schnitzler, Antina. 2013. "Traveling Technologies: Infrastructure, Ethical Regimes, and the Materiality of Politics in South Africa." Cultural Anthropology 28 (4): 670-693.

Von Schnitzler, Antina. 2016. Democracy's Infrastructure: Techno-Politics and Protest after Apartheid. Princeton: Princeton University Press.

Wolpe, Harold. 1972. "Capitalism and Cheap Labour-Power in South Africa: From Segregation to Apartheid." Economy and Society 1 (4): 425-456.

Yako, St. J. Page. 1983. Umtha Welanga. King William's Town: Afrikaanse Pers Boekhandel.

Young, Robert J. C. 2016. Postcolonialism: An Historical Introduction. 1st ed. Oxford: Wiley-Blackwell. 